\title{
Flood Risk Evaluation in Urban Spaces: The Study Case of Tormes River (Salamanca, Spain)
}

\author{
Marco Criado ${ }^{1}$, Antonio Martínez-Graña ${ }^{1, *} \mathbb{B}$, Javier Sánchez San Román ${ }^{1}$ and \\ Fernando Santos-Francés ${ }^{2}$ \\ 1 Department of Geology, Faculty of Sciences, University of Salamanca, 37008 Salamanca, Spain; \\ marcocn@usal.es (M.C.); javisan@usal.es (J.S.S.R.) \\ 2 Department of Soil Sciences, Faculty of Environmental Sciences, Avenue Filiberto Villalobos, \\ 119, University of Salamanca, 37007 Salamanca, Spain; fsantos@usal.es \\ * Correspondence: amgranna@usal.es; Tel.: +34-923-294546
}

Received: 10 November 2018; Accepted: 18 December 2018; Published: 20 December 2018

\begin{abstract}
The expansion of cities towards flood zones, and the increasingly frequent episodes of torrential rains arising from global warming, mean that the population is becoming more exposed to floods. Due to this, a correct assessment of flood events is of great help in the development of preventive actions, planning and resource management, or interventions. For this reason, in this work we aim to establish guidelines to assess the hazard, exposure, and vulnerability of the population and its properties to flood events, using Hec-Ras for the simulation of the flood and ArcGis and GeoHecRas to treat geographic information and prepare the cartography. The study was focused on the Tormes River in Salamanca (Spain). We studied three return periods with different probabilities of occurrence and intensity, corresponding to 5, 100, and 500 years. The flow corresponding to each episode was calculated, along with the extension, speed, and depth that would be achieved in each case. Then, the probability of occurrence was delimited, as well as the magnitude, allowing us to obtain different hazard maps. In addition, the areas of greatest hazard to people and property were established for each event. Regarding the exposure, the areas and land use, infrastructure, and buildings that would be flooded in each case were identified, quantifying the extension or length of the affected properties at the different levels of hazard in each case. Additionally, the vulnerability of the different buildings and exposed infrastructure was studied. Finally, the flood risk was estimated by combining these three components.
\end{abstract}

Keywords: flood hazard; urban vulnerability; urban exposure; probability; GIS

\section{Introduction}

The world population is increasingly gathering in large urban environments [1,2], and in 2050 it is estimated that $68 \%$ of the world population will be concentrated in urban agglomerations, compared to the current 55\% [3]. Given this fact, it is vital to incorporate analysis of the environment and natural risks in resource planning and territorial planning, especially when defining new areas that may be urbanized, in order to guarantee greater protection for the population and their properties [4-8].

According to the Center for Research on the Epidemiology of Disasters (CRED) and the United Nations Office for Disaster Risk Reduction (UNISD) in the period between 1998-2017, floods were the events that caused the greatest number of disasters (3148 cases, accounting for $43.4 \%$ of registered disasters), affecting 2 billion people, of whom 142,088 died (11\% of total deaths, after those caused by earthquakes, storms, and extreme temperatures). The economic losses of floods reached 65.600 billion dollars ( $23 \%$ of the total losses caused by natural disasters, after tropical storms and earthquakes). Fortunately, in contrast with an increasing number of events and economic losses, the trend in human 
deaths related to flooding indicates a decrease, mainly due to meteorological systems and alert systems [9].

Another aspect of the impact of floods on society to take into account is the increase in extreme weather events linked to global warming [10], which increase the virulence of floods and their hazard [11-16]. In addition, Jongman [17] predicted that in 2050 extreme flood events will occur more frequently, shifting from every 50 to every 30 years, while damage cycles will occur every 10 years instead of every 16 years. The related losses in Europe would go from 4.9 billion annually to 23.500 billion, an increase of $380 \%$, due to climate change and GDP increase. However, if about 1.750 billion is invested in risk prevention and mitigation measures, by 2050 the losses could be reduced by $30 \%$ (approximately 7 billion). In contrast, in certain regions the risk of flooding will decrease due to global warming, such as in areas of Northeastern Europe, where it will cause less snow accumulation than occurs at present [18-21].

Due to urban expansion and the generalized invasion of flood plains [22,23], and the higher frequency of extreme events that cause floods [24], it is important to study and simulate floods in order to mitigate the damage they cause [25-27]. The damage can affect people, causing human losses, increased risk of spreading diseases, eviction of homes, drownings, injuries, and other problems [28-30]; or it may result in economic losses related to basic services-electricity, water, telephone, or the Internet-or infrastructure, such as the destruction and/or flooding of roads and bridges, deterioration of homes, or destruction of crops [31-34]. In relation to this, the impacts caused by floods on water supply and evacuation networks are important, due to which several authors have developed methods to analyze these risks $[35,36]$ with which the safety and reliability of these networks has been improved [37].

Generally, a flood consists of the overflow of a river outside its natural course, causing the temporary flooding of the surrounding lands [38]. There are different types depending on the agents that originate it. These may be natural, such as periods of heavy rains or snowmelt, or be caused by derivatives of human action, such as the breakage of dams, malfunction of dams, or damming or deforestation of large areas. In these latter cases the flood is considered a technological risk, and not natural. Broadly speaking, flooding may be slow and progressive, characteristic of prolonged periods of intense rainfall in watersheds, or involve a sudden and rapid flow, characteristic of episodes of torrential rains in short periods of time, which mainly affect small and steep basins.

The risk of flooding corresponds to the set of losses (human, economic, ecological, and so forth) that are expected due to the occurrence of a flood episode. The risk analysis covers three phases: risk factors analysis (on which this work focuses); risk assessment (in which the losses are estimated); and analysis and design of risk mitigation measures. In relation to the risk factors, they include the hazard, exposure, and vulnerability, and the conjunction of these factors simultaneously is the overall risk [39]. These risk factors have been widely used by various authors to estimate flood risk and related losses [40-45].

The hazard is related to magnitude (susceptibility to risk from the conditioning or passive factors such as the topography or geological substrate) and the severity and frequency with which the agent that causes the risk is expressed (probability of triggering factors). In the case of floods, the hazardousness corresponds to the depth, speed, and extension reached by the sheet of water in each event. Therefore, to determine the hazardousness, we analyze the magnitude and probability of the occurrence of each event.

Exposure corresponds to the properties (human, material, ecological, economic, and so forth) that can be damaged by the action of the danger according to its location (elements at risk). These properties may vary over time and, currently, due to economic development, population growth, and climate change, they are increasing [46]. We only estimate how vulnerable these elements are according to their location, and in the case of floods, it depends mainly on the distance to the channel from where the element is located. On the other hand, vulnerability refers to the expected loss (which could be material or social) of a specific element exposed to the risk —in this case, to the flood-and depends on 
the intrinsic or specific characteristics of each exposed element [47-49]. Based on these considerations, the possible mitigation measures existing in each case can be taken into account.

For these reasons, the objective of this work is to analyze the existing flood risk in an urban environment for events of different magnitude and probability. In this case, in Salamanca, a World Heritage Site with many historical infrastructures of great value in the river environment (a Roman bridge, churches, convents, and monasteries). On the one hand, this will allow delimiting of the areas, infrastructures, and buildings that could be affected by these floods, and the hazard, exposure, and vulnerability in each zone. It will be possible to use this information to delimit the unfit areas to be urbanized due to the risk of flooding, and to elaborate preventive measures or plans of action in case of flooding of the elements classified as vulnerable. On the other hand, the lacking studies of the flood risks in this city mean that the urban development and infrastructures on the floodplains have been partially limited. This work can help urban managers in the initial stages of urban planning when defining new urbanization areas that do not entail risk for the population.

To achieve these objectives, we propose an easy and low-cost method that allows integrating in its different phases a large part of the parameters involved in floods. The data are integrated in a Geographical Information System (GIS) and computed with Hec-GeoRas (Hydrologic Engineering Center of US Army Corps of Engineers, USA), which together with the use of LIDAR Digital Elevation Model (DEM) data of $1 \mathrm{~m}$ resolution, making it a more accurate method that will optimize the flood mapping.

The use of Hec-Ras (Hydrologic Engineering Center of US Army Corps of Engineers, USA) for flood's modeling and the design of flood mapping with ArcGis (ESRI, USA) has been widely used in the study and modeling of floods. The use of Hec-GeoRas and the increasingly use of greater and greater precise DEM have allowed to improve the accuracy of this type simulations, so the information available for flood management has improved [50-53]. However, several authors criticize the effectiveness of flood mapping in flood assessment.

In the last few years, some authors have developed simulation models of floods with diverse mathematical basis, which aim to solve the limitations of traditional models, as well as to seek the adaptation of models to specific time-space cases. Nowadays, there are a great diversity of models (mainly, empirical methods, based in observations; hydrodynamic models, mathematical models that attempt to replicate fluid motion, and depending on their spatial representation of the floodplain flow, the models can be dimensionally grouped into 1D, 2D, and 3D models; and simplified methods, non-physics-based) used in flood risk mapping, flood damage assessment, real-time flood forecasting, flood related engineering, water resources planning, river bank erosion, and floodplain sediment transport, contaminant transport, floodplain ecology, river system hydrology, or catchment hydrology [54]. Additionally, many authors have focused their efforts on identifying the impact that different parameters—such as roughness or vegetation—have on the water dynamics in floods $[55,56]$.

\section{Description of the Study Area}

This study focuses on the Tormes River as it passes through Salamanca and its surroundings, as well as on a small tributary (Zurguen stream) that pours its waters into the Tormes in this city (Figure 1). The Tormes River divides the city of Salamanca into two halves, and determines the spatial configuration of the city and outskirts, bringing almost 200,000 inhabitants together. The Tormes is born in the Mountain of Gredos and travels 150 kilometers before reaching Salamanca, draining into a basin of $4132 \mathrm{~km}^{2}$ at this point. Historically, the Tormes has been the protagonist of multiple episodes of flooding, having recorded 35 historical floods between the XII-XIX centuries [57]. In the middle of the 20th century the Santa Teresa reservoir, which regulates the flow of the Tormes, was built upstream from Salamanca, and the virulence of the floods decreased. However, the subsequent expansion of the city of Salamanca along the alluvial plains of the Tormes, which has been done without detailed flood studies, makes it a good case for the study of floods. 

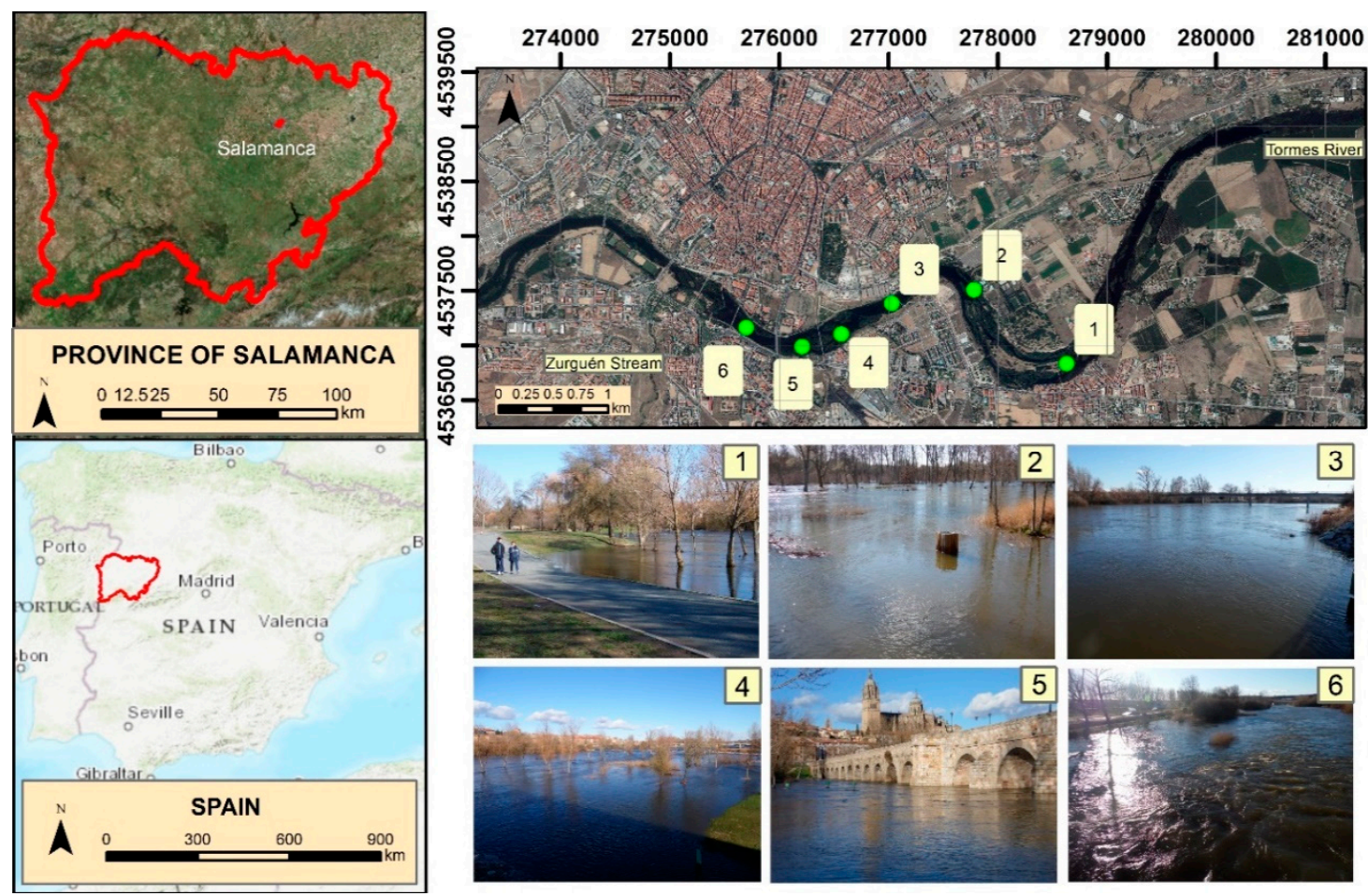

Figure 1. Study area and Tormes River in: (1) Fluvial island, in Santa Marta de Tormes; (2) "La Aldehuela", in Cabrerizos; (3) Next to the water treatment plant of Salamanca; (4) Upstream of the Roman bridge; (5) Close to Roman Bridge and the Cathedrals; (6) Beside the hospital and the "Salas Bajas" sport center.

\section{Materials and Methods}

The periods of return studied (T) correspond to 5 (T5), 100 (T100), and 500 (T500) years. The T5 corresponds to episodes of high probability and low magnitude, the T100 with episodes of medium probability and intensity, and the T500 with events of low probability but virulence.

To simulate the floods in each scenario, we differentiated two stages: the hydrological phase and the hydraulic phase. In the first, the maximum flows that exist for each $\mathrm{T}$ were estimated, and in the second, the flood was modeled, and we obtained the evolution of the water sheet along the process.

For the study of design flows, we divided the study into three sections: the Zurguén section, upper section of the Tormes, and lower section of the Tormes (after merging with Zurguén). The Tormes design flows were obtained from a historical series of maximum annual flows recorded in the Salamanca gauging station from 1979-2014 (Table 1). These data were treated using the Gumbel method, which determines the maximum flow rate for each $\mathrm{T}$ as a function of the mean and standard deviation of the flows obtained in the series. On the other hand, for the calculation of the maximum flow rates of the Zurguén stream, due to the absence of gauging stations an indirect estimation based on the rational method was employed that uses as parameters the maximum daily average rainfall for a certain $\mathrm{T}$, intensity of precipitation, soil runoff coefficient, and surface of the basin.

For the hydraulic phase, the channel of the rivers was first modeled (the main channel, banks, and alluvial plain were delimited). For this, ArcGis 10.5 and the extension Hec-GeoRas, and a $1 \times 1$ DEM and an aerial image as a base supplied by the National Geographic Institute of Spain, were used. Subsequently, the channel typology was exported to the Hec-Ras program, which simulates the flood. The Hec-Ras program, based on the maximum flow rates obtained for each scenario, and the configuration of the channel, simulated the extension, depth, and speed that the volume of water would present in each place in the different $\mathrm{T}$ scenarios. Finally, this information was exported again to ArcGis 10.5, and the corresponding cartography was elaborated, related to the extension, depth, and speed that the water presents in each scenario. 
Table 1. Maximum annual instantaneous flow for each year of the series [58].

\begin{tabular}{|c|c|c|c|c|c|c|c|c|c|}
\hline Year & $79-80$ & $80-81$ & $81-82$ & $82-83$ & $83-84$ & $84-85$ & $85-86$ & $86-87$ & 87-88 \\
\hline $\mathrm{Q}_{\mathrm{m}}$ & 41.7 & 17.38 & 118.7 & 55.3 & 138.9 & 138.9 & 109.4 & 98.7 & 126.6 \\
\hline Year & 88-89 & $89-90$ & 90-91 & $91-92$ & $92-93$ & 93-94 & 94-95 & $95-96$ & 96-97 \\
\hline $\mathrm{Q}_{\mathrm{m}}$ & 26.5 & 378.9 & 99.1 & 20.56 & 14.9 & 176.9 & 33.9 & 316.8 & 252.0 \\
\hline Year & $97-98$ & 98-99 & 99-00 & 00-01 & 01-02 & $02-03$ & 03-04 & 04-05 & 05-06 \\
\hline $\mathbf{Q}_{\mathrm{m}}$ & 527.9 & 22.0 & 98.3 & 387.0 & 46.5 & 444.0 & 157.0 & 43.9 & 66.5 \\
\hline Year & $06-07$ & 07-08 & 08-09 & 09-10 & $10-11$ & 11-12 & $12-13$ & 13-14 & 35 years \\
\hline $\mathrm{Q}_{\mathrm{m}}$ & 270.0 & 136.0 & 55.3 & 189.0 & 168.0 & 50.4 & 205.6 & 172 & \\
\hline \multicolumn{10}{|c|}{ Annual Studied Flows Statistics } \\
\hline \multirow{2}{*}{\multicolumn{2}{|c|}{ Statistics }} & \multicolumn{4}{|c|}{ Mean } & \multicolumn{4}{|c|}{ Standard dev. } \\
\hline & & \multicolumn{4}{|c|}{148.70} & \multicolumn{4}{|c|}{129.97} \\
\hline
\end{tabular}

Concerning to the analysis of risk factors, one was carried out for each scenario (T5, T100, and T500). This way, the different hazard levels, exposure, and vulnerability for each of the return periods were analyzed. The magnitude was obtained as a result of combining the depth and speed reached by the water sheet in each case. The magnitude, together with the probability, determines the hazard. The exposure was determined by delimiting the buildings, areas, or infrastructure affected by the flooding of each scenario. The vulnerability was determined through a field campaign studying the characteristics of each exposed element.

In relation to the magnitude, the speed and depth raster layers obtained after the analysis with the Hec-Ras and Hec-GeoRas program were reclassified and three types of intensity identified: low (1), medium (2), and high (3) (Table 2). Then, the rasters are multiplied (velocity: 1, 2, $3 \times$ depth: 1, 2, 3), and the results $(1,2,3,4,6,9)$ are reclassified into levels of high (9), medium $(4,6)$, and low magnitude $(1,2,3)$. For the elaboration of the hazard map, the possible affectation to properties was distinguished, which corresponded to the three levels of magnitude established. Low hazard areas do not generally involve property losses, with only small objects and vehicles being vulnerable. The zones of medium hazard can expect an impact on weak structure buildings. In areas of high hazard, any type of construction may be affected. In addition, hazard maps include areas that present a hazard to people based on the speed and depth of the water. These danger zones for people are those with depths greater than one meter or with water velocity greater than $1 \mathrm{~m} / \mathrm{s}$, and also those that present with a product depth $\times$ speed greater than 0.50 .

Table 2. Classification criteria proposed by the authors to evaluate the magnitude.

\begin{tabular}{cccccccc}
\hline & \multicolumn{3}{c}{ Velocity $(\mathrm{m} / \mathrm{s})$} & \multicolumn{5}{c}{ Depth $(\mathrm{m})$} \\
\hline Magnitude & Low & Medium & High & Magnitude & Low & Medium & High \\
\hline Speed & $<1$ & $1-2$ & $>2$ & Depth & $<0.5$ & $0.5-2$ & $>2$ \\
\hline
\end{tabular}

In the context of the elements present in the river environment, first of all, a classification of land uses was obtained from the entire study sector of the Soil Occupation Information System of Spain. Then, this classification was refined with orthoimages and field work, to better specify the elements exposed to the different scenarios.

After this, the exposure of the elements present in the river banks was analyzed (Table 3). To do this, the hazard mapping for each return period was superimposed on the cartography of land uses and exposed elements. In this way, the areas of land, infrastructure, and buildings that could be affected by each event with a high, medium, or low magnitude were identified, giving rise to high, medium, or low exposures, respectively. Next, we estimated the area of each type of land use that was 
flooded in each episode. Infrastructure and buildings affected by water were digitized in vector files, after which the length of infrastructure and the number of buildings that could be affected in each scenario were estimated.

After assessing the exposure, the vulnerability of these elements identified as exposed to the flood was analyzed. To insert the value of the vulnerability in the risk analysis, the different elements exposed to the flood were grouped according to their constructive characteristics, after being reclassified according to their high, medium, or low vulnerability (Table 3).

Table 3. Types of exposed elements and vulnerability that they present.

\begin{tabular}{clcc}
\hline Exposure & \multicolumn{1}{c}{ Types of exposed elements } & Rulnerability \\
\hline \multirow{2}{*}{ Road infrastructures } & \multicolumn{1}{c}{ Cycle lane and unpaved roads } & Medium \\
\cline { 2 - 3 } Buildings & Flat, chalet, duplex, single family home, industrial, education, sports-free time and others & Medium \\
\cline { 2 - 3 } & Farming and Tool shed & High \\
\hline \multirow{2}{*}{ Land Use } & Riparian vegetation, green areas, grasslands, empty lands and others & Low \\
\cline { 2 - 3 } & Crops and industrial & Medium \\
\cline { 2 - 3 } & Metropolitan area, sports-free time and education & High \\
\hline
\end{tabular}

Finally, the flood risk of the Tormes as it passes through Salamanca was estimated. To estimate the final risk, different levels of hazard, exposure and vulnerability were reclassified (High $=3$, Medium $=2$, Low $=1$ ). Subsequently, these three parameters, and taking into account the defined intervals, are combined according to the risk estimation formula [59] (Equation 1). As a result of the multiplication, values of $1,2,3,4,6,8,9,12,18$, and 27 units are obtained, which are reclassified, giving rise to flood risk categories: very low ( 1 and 2 units), low ( 3 and 4$)$, medium ( 6 and 8 ), high ( 9 and $12)$, and very high (18 and 27).

$$
\text { Risk }=\text { Hazard } \times \text { Exposure } \times \text { Vulnerability }
$$

\section{Results and Discussion}

\subsection{Design of Flood Events}

In order to model the floods in each scenario, the extension, depth and velocity of the volume of water were determined with Hec-Ras. Previously, the corresponding return flows that we estimated were inserted (Table 4). Hec-Ras simulates the transition of these flows through the channel, and the resulting information was processed with ArcMap 10.5, allowing the depth (Figure 2) and velocity (Figure 3) cartographies of the water sheet for the return periods of 5, 100, and 500 years to be obtained. Obviously, the greatest depths will be reached in the areas corresponding to the channel of the river, similar to what happens with speed, although this may vary according to the depth and type of surface (roughness of the ground) over which the water flows in every moment.

Table 4. Design flows $\left(\mathrm{m}^{3} / \mathrm{s}\right)$ for each section in the different return periods.

\begin{tabular}{cccc}
\hline \multirow{2}{*}{ Return Periods (T, in years) } & \multicolumn{3}{c}{ Section } \\
\cline { 2 - 4 } & Tormes I & Zurguén & Tormes II \\
\hline $\mathrm{T}=5$ & 217.3 & 106.3 & 323.6 \\
\hline $\mathrm{T}=100$ & 635.2 & 220.1 & 855.3 \\
\hline $\mathrm{T}=500$ & 926.0 & 307.6 & 1233.6 \\
\hline
\end{tabular}





Figure 2. Water depth $(\mathrm{m})$ in the different scenarios: $(\mathbf{A}) \mathrm{T}=5$ years; $(\mathbf{B}) \mathrm{T}=100$ years; and $(\mathbf{C}) \mathrm{T}=500$ years.

\subsection{Probability and Magnitude}

The flood probability of the different zones surrounding the Tormes channel depends on the magnitude of the event in question. The banks and spaces near the river present higher probabilities, while in the furthest zones the probability is lower, due to requiring the occurrence of a high magnitude event (Figure 4).

The magnitude (Figure 5) is always higher in the areas near the channel, considering that the depth and velocity are higher. The magnitude is lower in the floodplains, although in the events with a greater return period it is observed that the zones of high and medium magnitude increase and expand towards them. 

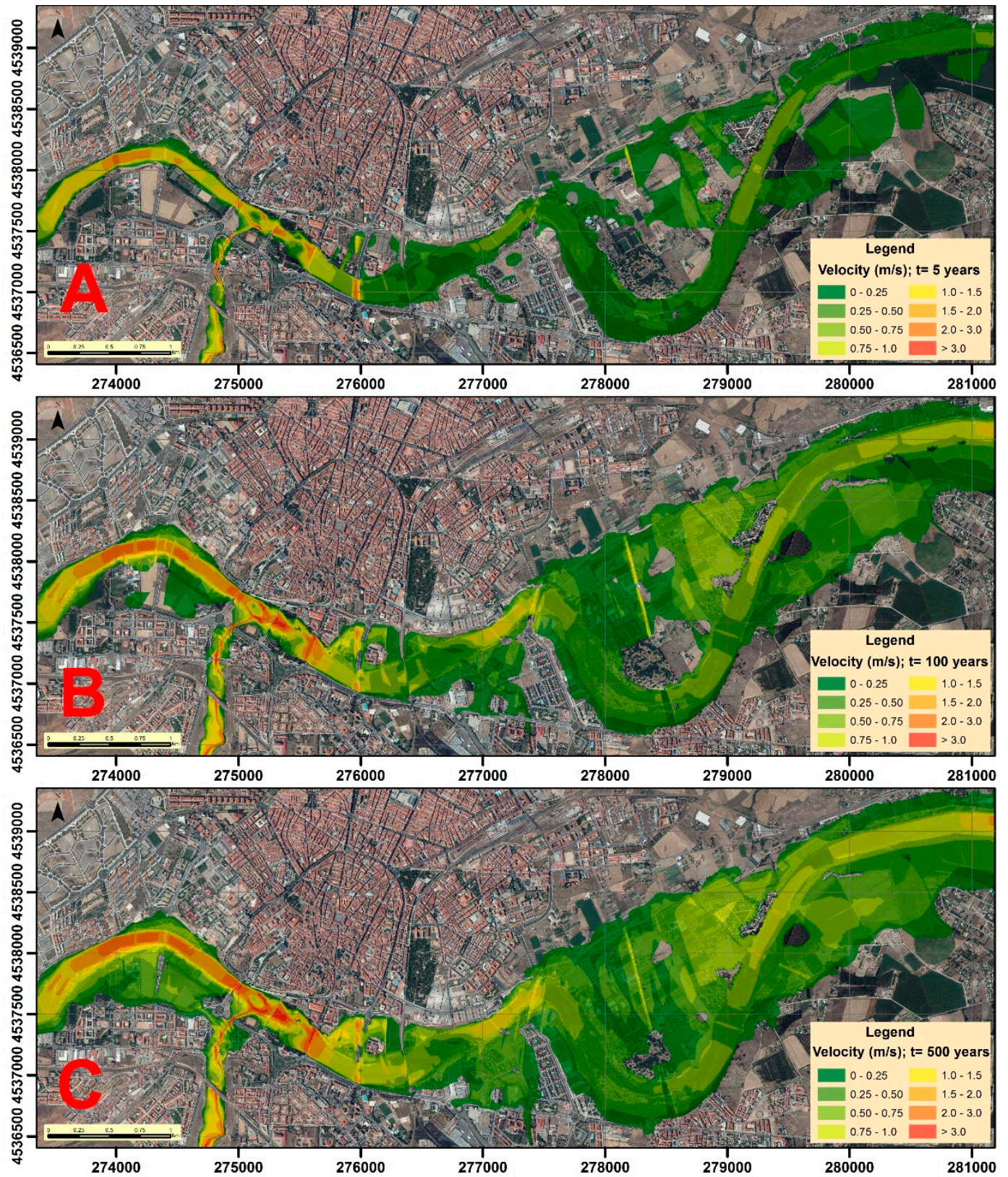

Figure 3. Water velocity $(\mathrm{m} / \mathrm{s})$ in the different scenarios: $(\mathbf{A}) \mathrm{T}=5$ years; $(\mathbf{B}) \mathrm{T}=100$ years; and $(\mathbf{C}) \mathrm{T}=500$ years.

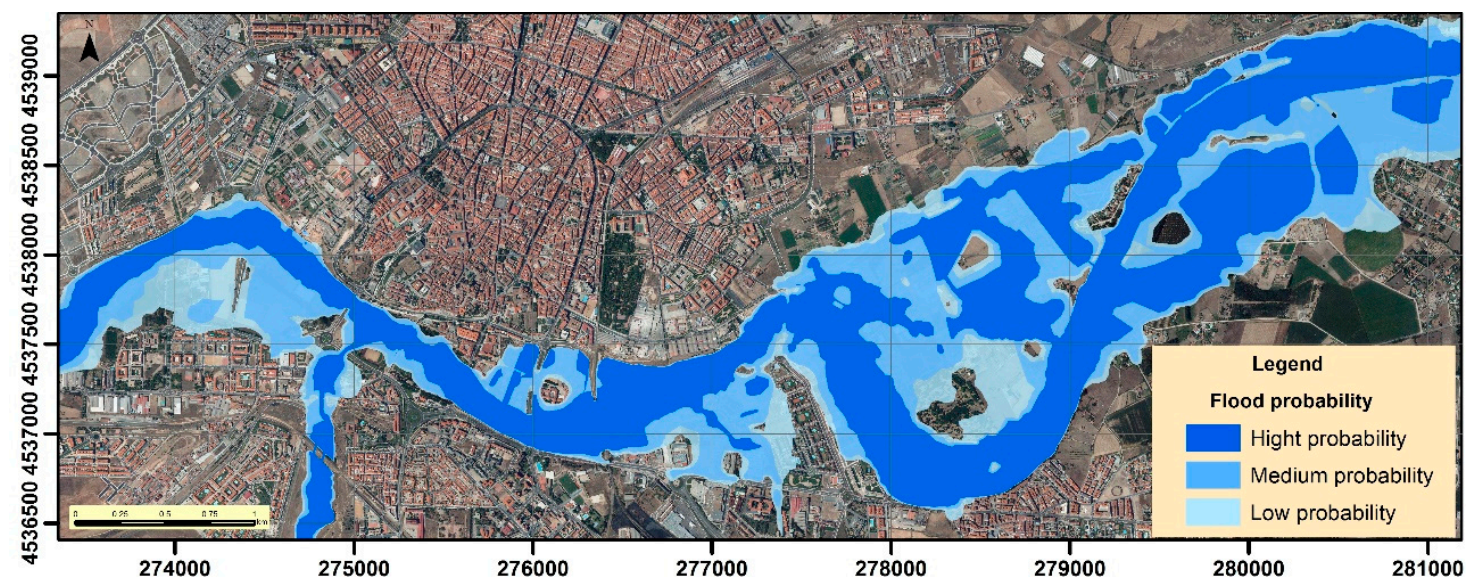

Figure 4. Flood probability of the areas surrounding the river. 

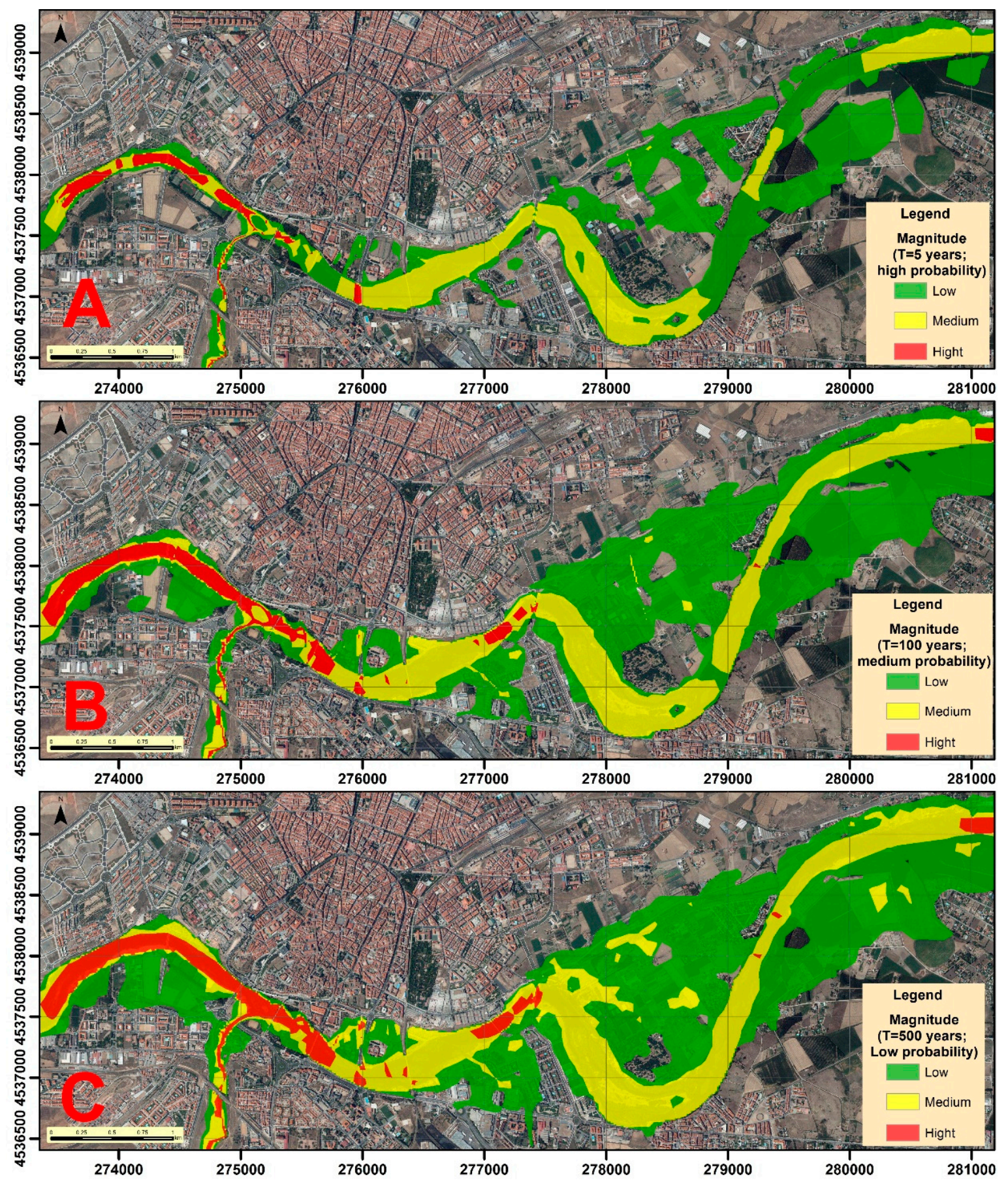

Figure 5. Magnitude of floods for each return period: $(\mathbf{A}) \mathrm{T}=5$ years; $(\mathbf{B}) \mathrm{T}=100$ years; and $(\mathbf{C}) \mathrm{T}=500$ years.

\subsection{Hazard Map}

Hazard maps are developed from the magnitudes and probabilities studied in each return period (Figure 6). These maps indicate the existing hazard in each scenario for the people and the different properties. The risk to people is delimited by a mesh that indicates that the depth and speed of water at these points could cause a person to drown. The impact on properties is divided into three intervals: low, which entails danger for vehicles and light elements; medium, where weak and unstable constructions could succumb; and high, where all buildings and infrastructure could be damaged.

In relation to hazard zones for people, although this may vary according to the age and physical capabilities of each person, they are limited mainly to areas near the riverbed, and are scarce in the 
alluvial plains except in the events of greater magnitude. Regarding the danger for material goods, we can also see how the areas of impact are greater when the magnitude is greater and the probability is lower. The greatest hazard occurs in areas adjacent to the channel, being medium, or low in areas of the alluvial plain, due to the amplitude of the same that allows expansion of the water surface.
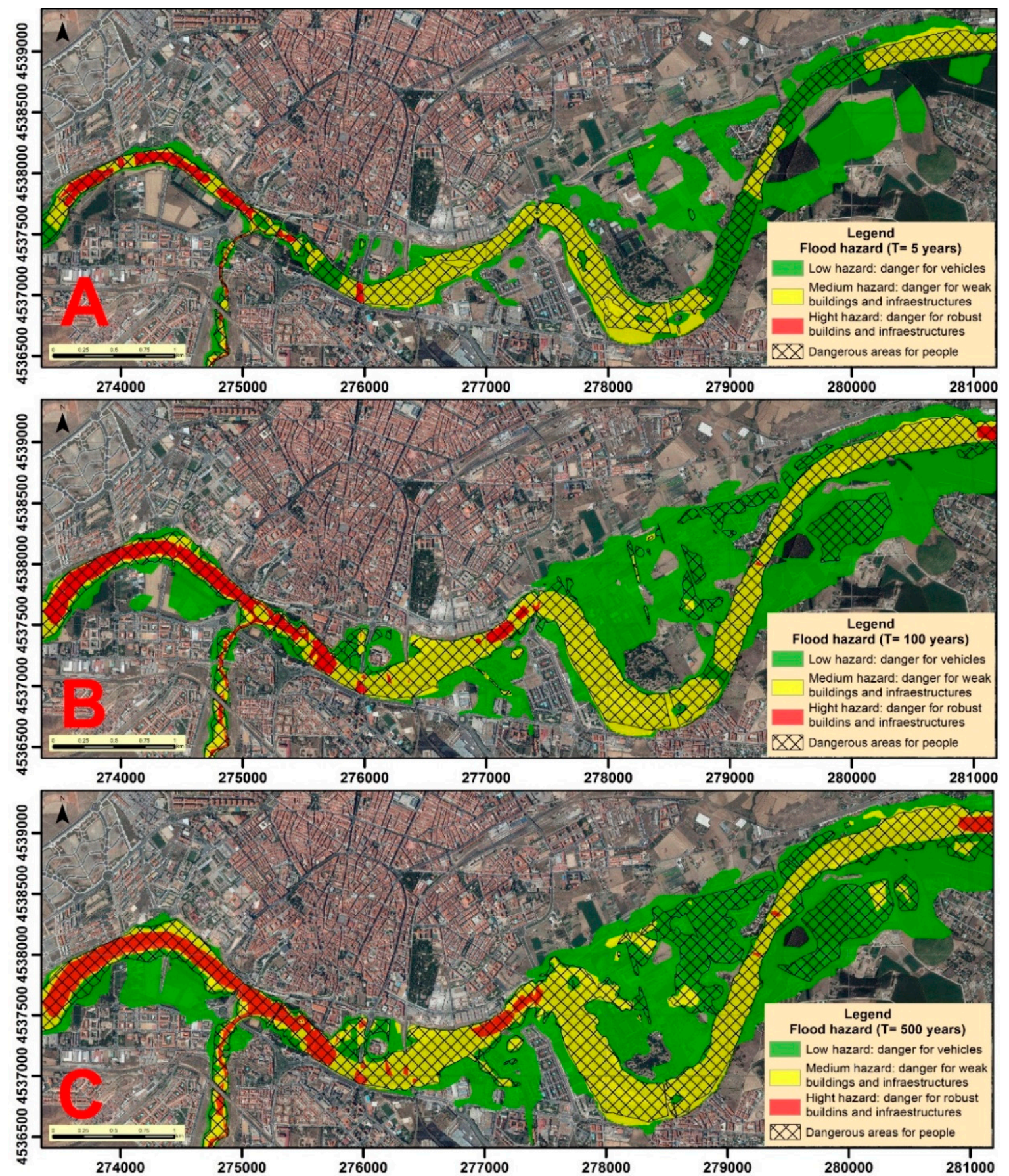

Figure 6. Hazard maps for each return period: $(\mathbf{A}) \mathrm{T}=5$ years; $(\mathbf{B}) \mathrm{T}=100$ years; and $(\mathbf{C}) \mathrm{T}=500$ years

\subsection{Exposure of Elements}

The different impact (high, medium, and low) of future floods on the elements that constitute the urban environment, according to their location, was evaluated. We studied the extent of the areas that will be flooded in each episode, and to what land use these areas correspond, as well as the infrastructure and buildings affected. 
In the cartography of land uses affected by the floods in each scenario (Figure 7), we can observe the different land uses exposed to high, medium, and low hazards, whose extension was calculated (Table 5). The main flooded areas correspond in all cases with agricultural areas, mainly intended for irrigated crops. The areas that support buildings are also quite affected, with up to $100 \mathrm{Ha}$ of urban land being impacted in an event of greater magnitude. Green areas, areas with riparian vegetation, and grasslands are also affected, while the rest of the land use types are only slightly affected.
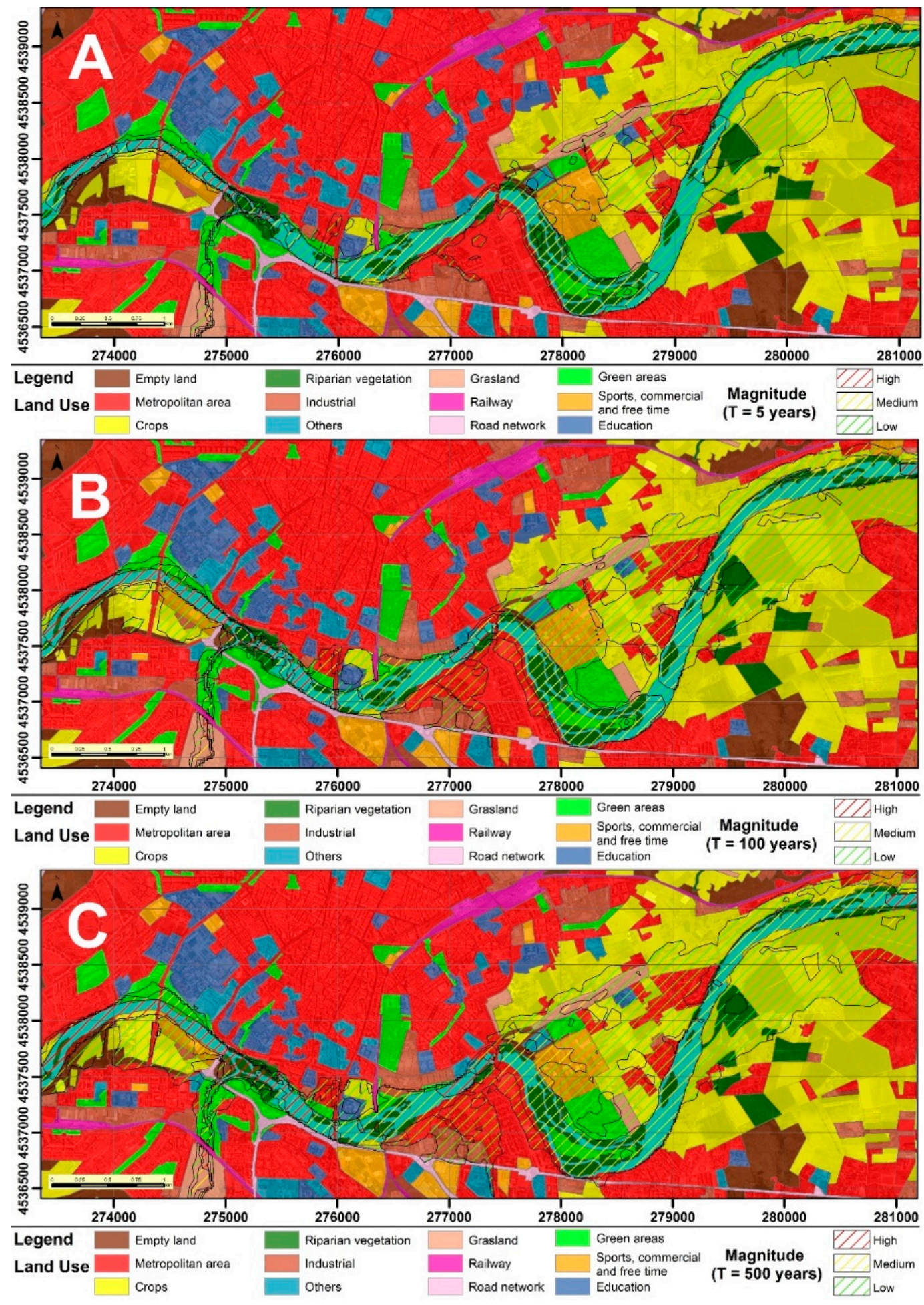

Figure 7. Flooded areas in each scenario according to their land use: $(\mathbf{A}) \mathrm{T}=5$ years; $(\mathbf{B}) \mathrm{T}=100$ years; and $(C) \mathrm{T}=500$ years. 
Table 5. Land use and extension (Ha) of flood zones in each scenario.

\begin{tabular}{cccccccccc}
\hline \multirow{2}{*}{ Land Use } & \multicolumn{3}{c}{$\mathrm{T}=\mathbf{5}$ years } & \multicolumn{3}{c}{$\mathrm{T}=\mathbf{1 0 0}$ years } & \multicolumn{3}{c}{$\mathrm{T}=\mathbf{5 0 0}$ years } \\
\cline { 2 - 11 } & High & Med & Low & High & Med & Low & High & Med & Low \\
\hline Metropolitan area & 0.46 & 4.51 & 27.56 & 0.78 & 10.20 & 65.52 & 1.62 & 14.83 & 86.70 \\
\hline Crops & 0.02 & 1.78 & 115.8 & 0.77 & 8.68 & 198.1 & 1.72 & 22.13 & 220.7 \\
\hline $\begin{array}{c}\text { Riparian } \\
\text { vegetation }\end{array}$ & 0.22 & 34.12 & 19.24 & 3.18 & 43.58 & 15.95 & 6.72 & 42.65 & 16.47 \\
\hline Green areas & 0.85 & 9.81 & 14.86 & 2.80 & 15.80 & 23.34 & 3.71 & 20.59 & 28.03 \\
\hline Grasslands & 0.57 & 1.42 & 11.90 & 1.13 & 3.34 & 15.07 & 1.61 & 6.20 & 16.46 \\
\hline Empty lands & 0.01 & 0.36 & 4.52 & 0.75 & 2.11 & 10.67 & 2.39 & 4.96 & 11.66 \\
\hline Industrial & - & 0.28 & 2.61 & - & 2.26 & 10.51 & - & 2.68 & 14.07 \\
\hline Education & - & - & 2.05 & - & 0.01 & 4.44 & 0.02 & 0.25 & 4.95 \\
\hline Sports-free time & 0.05 & 0.51 & 9.94 & 0.56 & 1.64 & 33.74 & 0.99 & 9.12 & 27.75 \\
\hline Others & - & 0.33 & 2.10 & 0.01 & 0.50 & 3.70 & 0.02 & 2.24 & 3.43 \\
\hline Total & 2.18 & 53.12 & 210.6 & 9.98 & 88.12 & 381.0 & 18.80 & 125.7 & 430.2 \\
\hline & & 265.9 & & & 479.1 & & & 574.7 & \\
\hline
\end{tabular}

On the other hand, the infrastructure and building exposition related to each scenario (Figure 8) was quantified when determining the length of affected infrastructure sections (Table 6), and when counting the number of vulnerable building types (Table 7). In terms of communication routes, roads are the most affected as a whole, however, among bike lanes and unpaved roads, the percentage of sections affected by high and medium exposures is higher, due to their predominance in areas close to the Tormes. Regarding the different types of buildings, none were identified in the high exposure areas. However, they are frequent in areas of medium and low exposure, especially buildings located in urbanizations of a certain purchasing power, corresponding mainly to duplex and detached houses. In areas near the river single-family homes are also common, along with vegetable patches. Flats and educational or industrial buildings are rare. On the other hand, buildings related to agriculture are very frequent. These include greenhouses, tool sheds in areas of kitchen gardens, and agricultural ships to house machinery. Buildings classified as "Other" generally refer to abandoned properties, or buildings that have other characteristics that do not allow them to be classified in another category because they are not representative.

Table 6. Impact of floods $(\mathrm{km})$ on different types of urban roads in each scenario.

\begin{tabular}{cccccccccc}
\hline \multirow{2}{*}{$\begin{array}{c}\text { Affection to Road } \\
\text { Infrastructures }\end{array}$} & \multicolumn{3}{c}{$\mathbf{T}=\mathbf{5}$ years } & \multicolumn{3}{c}{$\mathbf{T}=\mathbf{1 0 0}$ years } & \multicolumn{3}{c}{$\mathbf{T}=\mathbf{5 0 0}$ years } \\
\cline { 2 - 11 } & High & Med & Low & High & Med & Low & High & Med & Low \\
\hline Roads & 0.01 & 0.10 & 6.22 & 0.06 & 0.70 & 18.04 & 0.14 & 2.16 & 24.65 \\
\hline Cycle lane & - & 0.45 & 1.59 & 0.18 & 1.43 & 1.27 & 0.36 & 1.77 & 2.23 \\
\hline Unpaved road & - & 0.99 & 4.96 & 0.02 & 1.52 & 13.96 & 0.30 & 3.07 & 14.79 \\
\hline \multirow{2}{*}{ Total } & 0.01 & 1.54 & 12.77 & 0.26 & 3.65 & 33.27 & 0.80 & 7.00 & 41.67 \\
\cline { 2 - 10 } & & 14.32 & & & 37.18 & & & 49.47 & \\
\hline
\end{tabular}

Table 7. Number of buildings of each type affected in the different scenarios.

\begin{tabular}{cccccccccc}
\hline \multirow{2}{*}{ Affection to Buildings } & \multicolumn{3}{c}{$\mathrm{T}=\mathbf{5}$ years } & \multicolumn{3}{c}{$\mathrm{T}=\mathbf{1 0 0}$ years } & \multicolumn{3}{c}{$\mathrm{T}=\mathbf{5 0 0}$ years } \\
\cline { 2 - 11 } & High & Med & Low & High & Med & Low & High & Med & Low \\
\hline Flats & - & - & - & - & - & 2 & - & - & 8 \\
\hline Detached house & - & - & 85 & - & 1 & 151 & - & 1 & 171 \\
\hline Duplex & - & 1 & 11 & - & 1 & 57 & - & 2 & 96 \\
\hline Single family home & - & 2 & 17 & - & 4 & 32 & - & 6 & 46 \\
\hline Farming & - & 5 & 50 & - & 6 & 79 & - & 16 & 94 \\
\hline
\end{tabular}


Table 7. Cont.

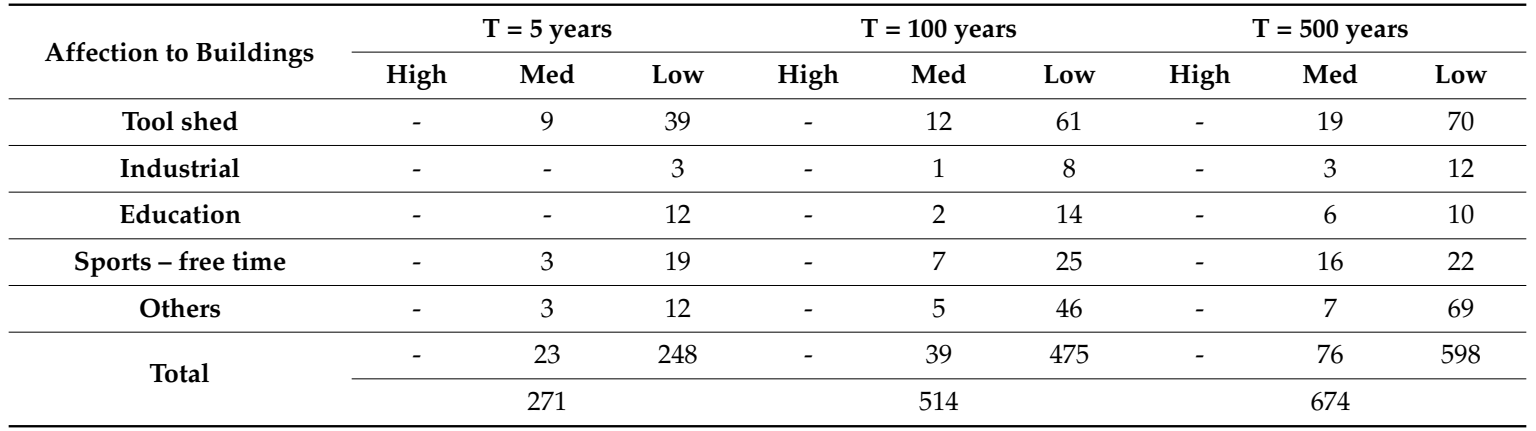
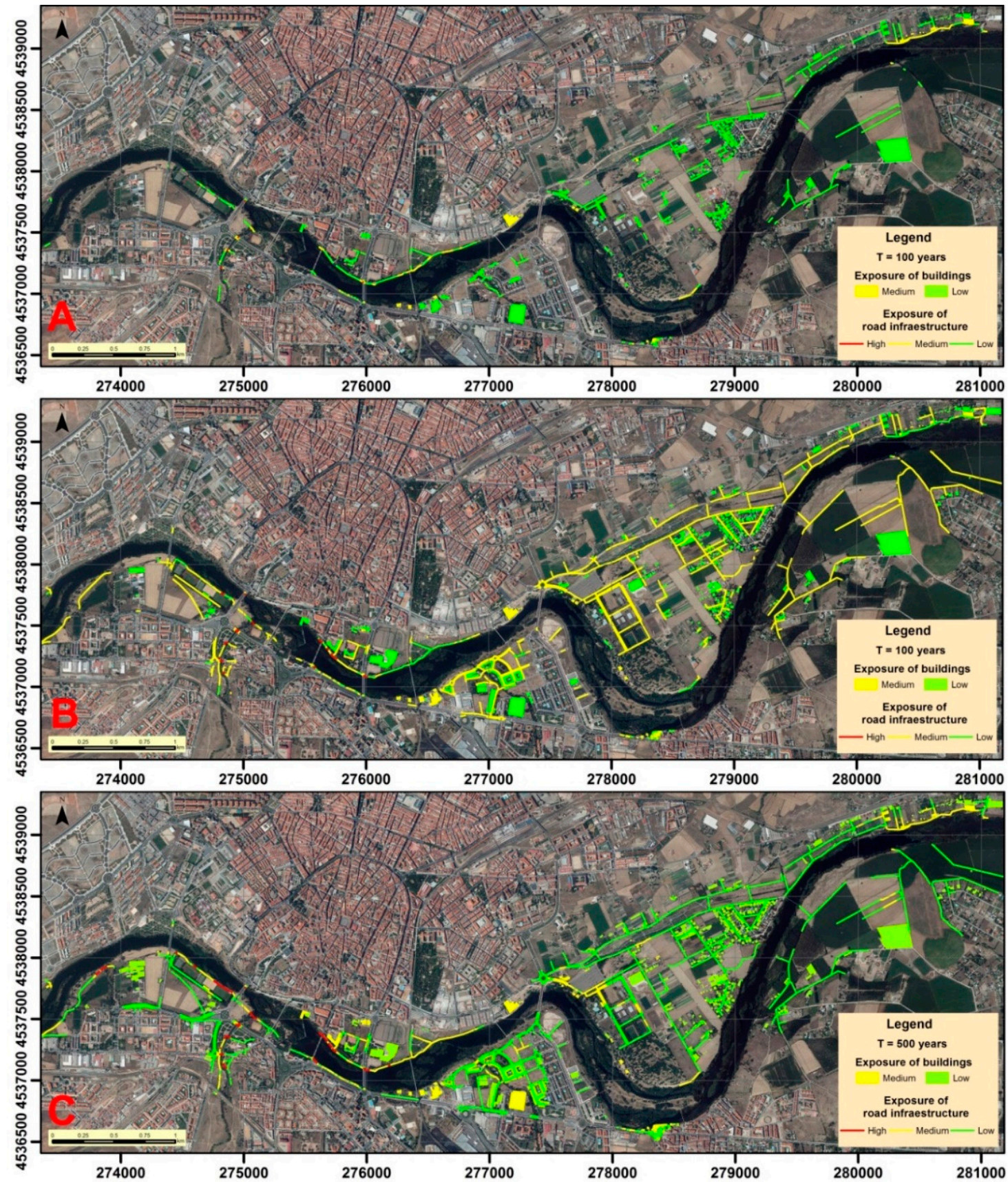

Figure 8. Exposure of the elements identified in the different return periods: (A) $\mathrm{T}=5$ years; (B) $\mathrm{T}=100$ years; and $(\mathbf{C}) \mathrm{T}=500$ years. 


\subsection{Vulnerability of Elements}

Vulnerability changes depending on the characteristics of each type of building, so the most vulnerable buildings are those designed to house agricultural tools and all buildings related to agricultural and livestock uses. The rest of the buildings could be considered low-medium vulnerability, due to their more robust structure, but because they tend to be in places with frequent human presence, they are considered of medium vulnerability (Figure 9).

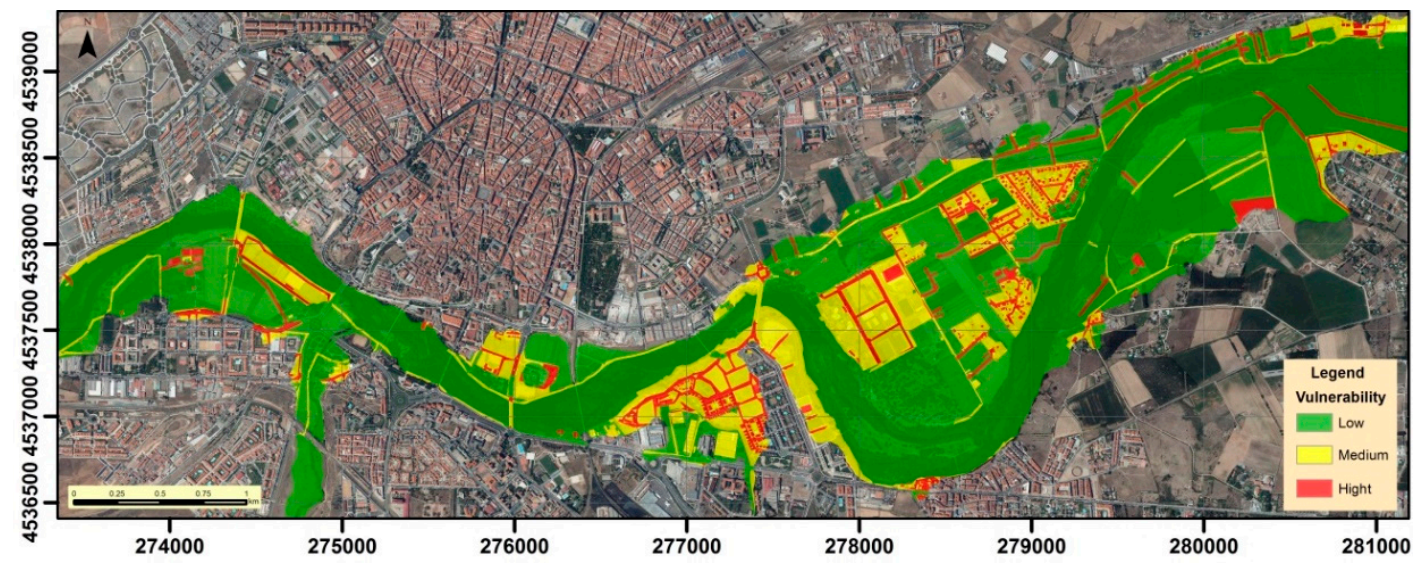

Figure 9. Vulnerability of the elements exposed to floods.

\subsection{Flood Risk}

Finally, regarding the risk of final flooding (Figure 10), the areas of greatest risk (very high risk) cover an area of $160.3 \mathrm{Ha}$, which correspond to those areas of greatest hazard, exposure and vulnerability, and are mostly linked to the Tormes channel and closer areas. At high risk, we find those elements most exposed and vulnerable to flood, including some communication routes and most buildings, accounting for an extension of $57.9 \mathrm{Ha}$. Medium risk covers an area of $124.2 \mathrm{Ha}$ and includes the rest of the exposed elements, especially communication routes and the areas surrounding them and those extensions whose main land use is to house buildings, infrastructure, and services of different types. The medium risk zones corresponds to areas of medium or high exposure and vulnerability, but of low hazard, or with highly hazardous areas, but low exposure and vulnerability. With low and very low risk of flooding, the rest of the extensions (covering areas of $72.2 \mathrm{Ha}$ and $278.9 \mathrm{Ha}$, respectively) appear, which correspond to areas of the Tormes floodplain, are generally far from the river, and in which agricultural activities are developed, although there are also extensions with pastures, riparian vegetation, or empty lands.

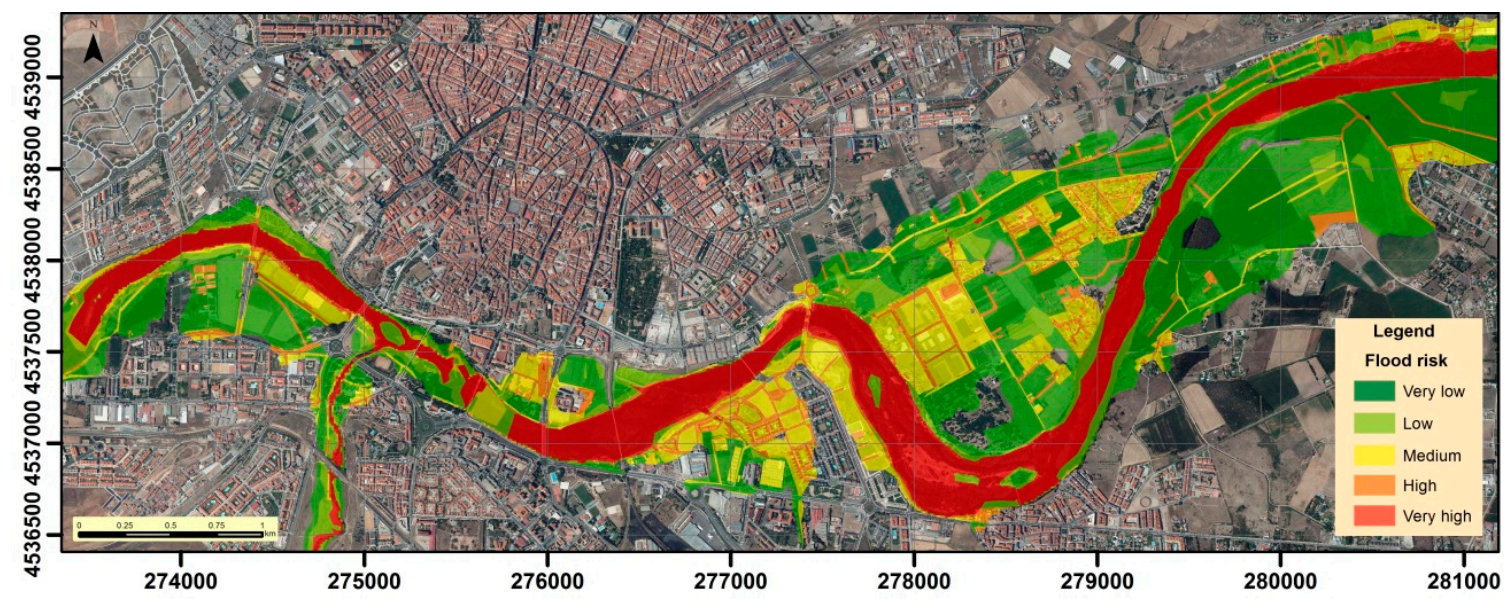

Figure 10. Flood risk estimated in the study area. 


\subsection{Discussion}

The obtained results show the impacts that will occur in the Tormes floodplain as it passes through the historic city of Salamanca in the different flood scenarios. With the risk mapping, first of all, a better management of the land uses can be carried out in this riversite, which is related to two concepts: (1) greater ease when managers limiting certain activities or uses in those exposed areas to the risk, although depending on the different type of risk, activities or uses compatible with each risk can be developed; and (2) greater security when urban planners allocating land uses to those areas of the riverbank that are not affected by the risk. Flood cartography has been presented as maps, which has been criticized by some authors, who affirm the inefficiency of this cartography due to it is not estimated by the planners. Some authors suggest that flood information should be presented on real and concrete 2D and 3D images, in a way that is more attractive and realistic [60], facts that can be achieved with this model, since with the generated layers and the ArcGis 2D images, 3D images, and flights can be design. In relation to this, in this work, the great extension of the study area acted in a limiting way when making this type of images, since only a part of that area could be represented. For this reason, numerous authors carry out studies in specific areas, using very large scales, improving even more the levels of precision [61-63]. Others authors maintain that the use of the flood information by governments and planers is due more to how information is exchanged with the planners than to the quality of the work [64], which is why some authors propose interactive work sessions of researchers and planners [65]. Other authors advise to integrate in the analysis other characteristics such as the demands of the social groups affected [66], an aspect that the proposed methodology does not agglutinate.

Regarding the method, although it is based on classic procedures, but of recognized solvency, it includes new elements that allow improving the results. This is the case of the Hec-Ras program, which is implemented in the GIS, in the form of Hec-GeoRas, so that the topographic description of flooded areas is precise, due to the $1 \mathrm{~m}$ resolution LIDAR DEM use [67]. Due to these DEM's precision, the accuracy of these models increases [68,69]. For the case of the estimation of return flows, two procedures are proposed to obtain it, which depends on whether there is a gauging station. In addition, the different artificial barriers existing in the river (as in the case of dykes or bridges) are implemented in the model, in such a way that it increases the sensitivity of the model. Additionally, this infrastructure implementation evaluation can be used to study the possible impact on floods that an infrastructure of a project wants to perform in a certain floodplain. Furthermore, it is possible to identify those infrastructures that are most exposed to risk and hazardousness too, and depending on this risk and its characteristics, preventive management measures can be designed.

In conclusion, the method can be used and adapted in different places and environments, since its variety of opportunities allows us to adapt it to any situation and spatial configuration. In this case, The Tormes River and the city of Salamanca were chosen, due it being a river with a large number of historical floods in a historical, artistic, and cultural city. Despite this, flood studies were very scarce and not very precise, which has led to an irregular and inconsistent development and soil occupation on the riverbank. We hope that with this work this scarcity will be corrected and the management of the banks of the Tormes in Salamanca will be more effective and safe for the population.

\section{Conclusions}

Natural risks cause great losses to society, both in human and socioeconomic terms, with floods being one of the risks that cause the greatest impact on society. Therefore, the procedure followed in this work is an essential tool to guarantee adequate protection of the population and correct management of territory and land use, which will also affect the proper maintenance of socio-economic resources.

The methodology used for the flood risk assessment is easy, fast, and cheap to apply, as well as being robust and precise in the topography description of flooded areas due to the use of the high resolution spatial information ( $1 \mathrm{~m}$ resolution LIDAR DEM) and the design and implementation in the model of all the anthropic elements located in the channel that affect the flood evolution. 
The topography and the estimation of the return flows allow us to simulate adequately the characteristics of the flood in each event, meaning the hazard of the event can be effectively evaluated. Regarding the exposure of different properties, the method allows resources to be saved by analyzing exposure for only those exposed to the hazard, pre-determined due to orthophoto and field work, and their vulnerability is also evaluated. In addition, a characteristic of this method is that it allows us to discern between hazard zones for people and hazard zones for material goods. Therefore, the method employed in this work is considered broad and valid, since it takes into account several factors involved in the risk analysis, and is not based on individualized analyses of each factor. Concerning the estimation of return flows, the use of volumetric flow reduces the error and increases the accuracy. Definitely, it is an ad hoc method, in which a multitude of case studies can be simulated due to the parameters and infrastructures that can be designed and taken into account in the procedure. Consequently, furthermore to being able to adapt the model to a multitude of scenarios, it allows the design of post-installation scenarios in the river environment of new elements that interfere with floods evolution, so that it can be used for preventive purposes.

By the Tormes River in Salamanca, there are many homes and a lot of infrastructure that could be exposed to floods because they are located in the floodplain of the river. For this reason, the employed methodology provides the basis and criteria so that authorities and governments can regulate land use and limit human activity in the floodplains through proper territorial planning. Also, the existence of this risk cartography will allow a better manage of those floodplain areas that are not affected by the risk of flooding. Due to LIDAR and ArcGis integration in the model, very creative information could be generated regarding the flood episodes, in order to achieve a greater impact on the receiver, as well as very concrete and real recreations. Moreover, the quantification of expected damages or losses for future flood events in different scenarios will be possible, and also enables the elaboration of action plans and risk mitigation measures in areas with exposed and vulnerable buildings and infrastructure.

Author Contributions: Conceptualization: M.C. and A.M-G.; methodology: J.S.S.R.; software: M.C.; validation: M.C., A.M-G.; formal analysis: J.S.S.R.; investigation: F.S.-F; resources: J.S.S.R.; data curation: M.C.; writing-original draft preparation: A.M-G.; writing-review and editing: M.C.; visualization: F.S.-F.; supervision: M.C.; project administration: A.M-G.; funding acquisition: A.M-G.

Funding: We This research was funded by projects: Junta Castilla y León SA044G18 and USAL (2017) 46AC0; and projects from the Ministry of Economy and Competitiveness CGL2015-67169-P and CGL2015-69919-R.

Conflicts of Interest: The authors declare no conflict of interest.

\section{References}

1. Angel, S.; Parent, J.; Civco, D.L.; Blei, A.; Potere, D. The dimensions of global urban expansion: Estimates and projections for all countries, 2000-2050. Prog. Plan. 2011, 75, 53-107. [CrossRef]

2. Seto, K.C.; Fragkias, M.; Güneralp, B.; Reilly, M.K. A meta-analysis of global urban land expansion. PLoS ONE 2011, 6, 2377. [CrossRef] [PubMed]

3. World Urbanization Prospects: The 2018 Revision. Available online: https://population.un.org/wup/ Publications / Files/WUP2018-KeyFacts.pdf (accessed on 15 October 2018).

4. Criado, M.; Martínez-Graña, A.; Santos-Francés, F.; Veleda, S.; Zazo, C. Multi-Criteria Analyses of Urban Planning for City Expansion: A Case Study of Zamora, Spain. Sustainability 2017, 9, 1850. [CrossRef]

5. Martínez-Graña, A.; Goy, J.L.; De Bustamante, I.; Zazo, C. Characterization of environmental impact on resources, using strategic assessment of environmental impact and management of natural spaces of "Las Batuecas-Sierra de Francia" and "Quilamas" (Salamanca, Spain). Environ. Earth Sci. 2014, 71, 39-51. [CrossRef]

6. UNISDR. Global Assessment Report on Disaster Risk Reduction (2011). Revealing Risk, Redefining Development. Summary and Main Findings; United Nations: New York, NY, USA, 2011.

7. Mustafa, A.; Bruwier, M.; Archambeau, P.; Erpicum, S.; Pirotton, M.; Dewals, B.; Teller, J. Effects of spatial planning on future flood risks in urban environments. J. Environ. Manag. 2018, 225, 193-204. [CrossRef] [PubMed] 
8. Santos-Francés, F.; Martínez-Graña, A.; Zarza, C.; Sánchez, G.; Rojo, P. Spatial Distribution of Heavy Metals and the Environmental Quality of Soil in the Northern Plateau of Spain by Geostatistical Methods. Int. J. Environ. Res. Public Health 2017, 14, 568. [CrossRef] [PubMed]

9. Paprotny, D.; Sebastian, A.; Morales-Nápoles, O.; Jonkman, S.N. Trends in flood losses in Europe over the past 150 years. Nat. Commun. 2018, 9, 1985. [CrossRef]

10. IPCC. Climate Change 2014: Impacts, Adaptation, and Vulnerability. Part B: Regional Aspects. Contribution of Working Group II to the Fifth Assessment Report of the Intergovernmental Panel on Climate Change; Barros, V.R., Field, C.B., Dokke, D.J., Mastrandrea, M.D., Mach, K.J., Bilir, T.E., Chatterjee, M., Ebi, K.L., Estrada, Y.O., Genova, R.C., Eds.; Cambridge University Press: Cambridge, UK; New York, NY, USA, 2014; 688p.

11. Lawrence, J.; Reisinger, A.; Mullan, B.; Jackson, B. Exploring climate change uncertainties to support adaptive management of changing flood-risk. Environ. Sci. Policy 2013, 33, 133-142. [CrossRef]

12. Alfieri, L.; Burek, P.; Feyen, L.; Forzieri, G. Global warming increases the frequency of river floods in Europe. Hydrol. Earth Syst. Sci. 2015, 19, 2247-2260. [CrossRef]

13. Kuklicke, C.; Demeritt, D. Adaptive and risk-based approaches to climate change and the management of uncertainty and institutional risk: The case of future flooding in England. Glob. Environ. Chang. 2016, 37, 56-68. [CrossRef]

14. Winsemius, H.C.; Aerts, J.C.; Van Beek, L.P.; Bierkens, M.F.; Bouwman, A.; Jongman, B.; Ward, P.J. Global drivers of future river flood risk. Nat. Clim. Chang. 2016, 6, 381. [CrossRef]

15. Jenkins, K.; Surminski, S.; Hall, J.; Crick, F. Assessing surface water flood risk and management strategies under future climate change: Insights from an Agent-Based Model. Sci. Total Environ. 2017, 595, 159-168. [CrossRef] [PubMed]

16. Tapia, C.; Abajo, B.; Feliu, E.; Mendizabal, M.; Martinez, J.A.; Fernández, J.G.; Laburu, T.; Lejarazu, A. Profiling urban vulnerabilities to climate change: An indicator-based vulnerability assessment for European cities. Ecol. Indic. 2017, 78, 142-155. [CrossRef]

17. Jongman, B.; Hochrainer-Stigler, S.; Feyen, L.; Aerts, J.C.; Mechler, R.; Botzen, W.W.; Bouwer, L.M.; Pflug, G.; Rojas, R.; Ward, P.J. Increasing stress on disaster-risk finance due to large floods. Nat. Clim. Chang. 2014, 4, 264. [CrossRef]

18. Dankers, R.; Feyen, L. Flood hazard in Europe in an ensemble of regional climate scenarios. J. Geophys. Res. Atmos. 2009, 114, D16. [CrossRef]

19. Ciscar, J.C.; Iglesias, A.; Feyen, L.; Szabó, L.; Van Regemorter, D.; Amelung, B.; Nicholls, R.; Watkiss, P.; Christensen, O.B.; Dankers, R.; et al. Physical and economic consequences of climate change in Europe. Proc. Natl. Acad. Sci. USA 2011, 108, 2678-2683. [CrossRef] [PubMed]

20. Rojas, R.; Feyen, L.; Bianchi, A.; Dosio, A. Assessment of future flood hazard in Europe using a large ensemble of bias-corrected regional climate simulations. J. Geophys. Res. Atmos. 2012, 117, D17. [CrossRef]

21. Vormoor, K.; Lawrence, D.; Schlichting, L.; Wilson, D.; Wong, W.K. Evidence for changes in the magnitude and frequency of observed rainfall vs. snowmelt driven floods in Norway. J. Hydrol. 2016, 538, 33-48. [CrossRef]

22. Poelmans, L.; Rompaey, A.V.; Ntegeka, V.; Willems, P. The relative impact of climate change and urban expansion on peak flows: A case study in central Belgium. Hydrol. Process. 2011, 25, 2846-2858. [CrossRef]

23. Beckers, A.; Dewals, B.; Erpicum, S.; Dujardin, S.; Detrembleur, S.; Teller, J.; Pirotton, M.; Archambeau, P. Contribution of land use changes to future flood damage along the river Meuse in the Walloon region. Nat. Hazards Earth Syst. Sci. 2013, 13, 2301-2318. [CrossRef]

24. Muis, S.; Güneralp, B.; Jongman, B.; Aerts, J.C.; Ward, P.J. Flood risk and adaptation strategies under climate change and urban expansion: A probabilistic analysis using global data. Sci. Total Environ. 2015, 538, 445-457. [CrossRef] [PubMed]

25. Fedeski, M.; Gwilliam, J. Urban sustainability in the presence of flood and geological hazards: The development of a GIS-based vulnerability and risk assessment methodology. Landsc. Urban Plan. 2007, 83, 50-61. [CrossRef]

26. Kaźmierczak, A.; Cavan, G. Surface water flooding risk to urban communities: Analysis of vulnerability, hazard and exposure. Landsc. Urban Plan. 2011, 103, 185-197. [CrossRef]

27. Veleda, S.; Martínez-Graña, A.; Santos-Francés, F.; Sánchez-San Roman, J.; Criado, M. Analysis of the Hazard, Vulnerability and Exposure to the Risk of Flooding (Alba de Yeltes, Salamanca, Spain). Appl. Sci. 2017, 7, 157. [CrossRef] 
28. Alderman, K.; Turner, L.R.; Tong, S. Floods and human health: A systematic review. Environ. Int. 2012, 47, 37-47. [CrossRef]

29. Munro, A.; Kovats, R.S.; Rubin, G.J.; Waite, T.D.; Bone, A.; Armstrong, B.; Beck, C.R.; Amlôt, R.; Leonardi, G.; Oliver, I. Effect of evacuation and displacement on the association between flooding and mental health outcomes: A cross-sectional analysis of UK survey data. Lancet Planet. Health 2017, 1, e134-e141. [CrossRef]

30. Walker-Springett, K.; Butler, C.; Adger, W.N. Wellbeing in the aftermath of floods. Health Place 2017, 43, 66-74. [CrossRef]

31. Armah, F.A.; Yawson, D.O.; Yengoh, G.T.; Odoi, J.O.; Afrif, E.K. Impact of floods on livelihoods and vulnerability of natural resource dependent communities in Northern Ghana. Water 2010, 2, 120-139. [CrossRef]

32. Sultana, M.; Chai, G.; Chowdhury, S.; Martin, T. Deterioration of flood affected Queensland roads-An investigative study. Int. J. Pavement Res. Technol. 2016, 9, 424-435. [CrossRef]

33. Pregnolato, M.; Ford, A.; Wilkinson, S.M.; Dawson, R.J. The impact of flooding on road transport: A depth-disruption function. Transp. Res. D Trans. Environ. 2017, 55, 67-81. [CrossRef]

34. Lyu, H.M.; Sun, W.J.; Shen, S.L.; Arulrajah, A. Flood risk assessment in metro systems of mega-cities using a GIS-based modeling approach. Sci. Total Environ. 2018, 626, 1012-1025. [CrossRef] [PubMed]

35. Pietrucha-Urbanik, K.; Tchórzewska-Cieślak, B. Water Supply System operation regarding consumer safety using Kohonen neural network. In Safety, Reliability and Risk Analysis: Beyond the Horizon, 1st ed.; Steenbergen, R.D.J.M., van Gelder, P.H.A.J.M., Miraglia, S., Vrouwenvelder, A.C.W.M., Eds.; Taylor \& Francis Group: London, UK, 2014; pp. 1115-1120.

36. Pietrucha-Urbanik, K.; Żelazko, A. Approaches to assess water distribution failure. Period. Polytech. Civ. 2017, 61, 632-639. [CrossRef]

37. Pietrucha-Urbanik, K.; Tchórzewska-Cieślak, B. Approaches to Failure Risk Analysis of the Water Distribution Network with Regard to the Safety of Consumers. Water 2018, 10, 1679. [CrossRef]

38. Directive 2007/60; EC-European Commission of the European Parliament: Brussels, Belgium, 2007; p. 23.

39. Kron, W. Flood risk = hazard · values · vulnerability. Water Int. 2005, 30, 58-68. [CrossRef]

40. Crichton, D. The risk triangle. In Natural Disaster Management, 1st ed.; Ingleton, J., Ed.; United Nations: Licester, UK, 1999; Volume 102, p. 103.

41. Department for Environment, Food and Rural Affairs. RED Outputs: Flood Risks to People. Phase 2. FD2321/TR1; The Flood Risks to People Methodology; Department for Environment, Food and Rural Affairs: London, UK, 2006.

42. Crichton, D. What can cities do to increase resilience? Philos. Trans. A Math. Phys. Eng. Sci. 2007, 2731-2739. [CrossRef]

43. Hansson, K.; Danielson, M.; Ekenberg, L.; Buurman, J. Multiple criteria decision making for flood risk management, 2013. In Integrated Catastrophe Risk Modeling: Supporting Policy Processes, 1st ed.; Amendola, A., Ermolieva, T., Linnerooth-Bayer, J., Mechler, R., Eds.; Springer: Berlin, Germany, 2013; Chapter 4; pp. 53-72.

44. Koks, E.E.; Jongman, B.; Husby, T.G.; Botzen, W.J. Combining hazard, exposure and social vulnerability to provide lessons for flood risk management. Environ. Sci. Policy 2015, 47, 42-52. [CrossRef]

45. Ermolieva, T.; Filatova, T.; Ermoliev, Y.; Obersteiner, M.; de Bruijn, K.M.; Jeuken, A. Flood Catastrophe Model for Designing Optimal Flood Insurance Program: Estimating Location-Specific Premiums in the Netherlands. Risk Anal. 2017, 37, 82-98. [CrossRef] [PubMed]

46. De Moel, H.; Aerts, J.C.; Koomen, E. Development of flood exposure in the Netherlands during the 20th and 21st century. Glob. Environ. Chang. 2011, 21, 620-627. [CrossRef]

47. Balica, S.F.; Popescu, I.; Beevers, L.; Wright, N.G. Parametric and physically based modelling techniques for flood risk and vulnerability assessment: A comparison. Environ. Model. Softw. 2013, 41, 84-92. [CrossRef]

48. Rufat, S.; Tate, E.; Burton, C.G.; Maroof, A.S. Social vulnerability to floods: Review of case studies and implications for measurement. Int. J. Disaster Risk Reduct. 2015, 14, 470-486. [CrossRef]

49. Zachos, L.G.; Swann, C.T.; Altinakar, M.S.; McGrath, M.Z.; Thomas, D. Flood vulnerability indices and emergency management planning in the Yazoo Basin, Mississippi. Int. J. Disaster Risk Reduct. 2016, 18, 89-99. [CrossRef]

50. Pistrika, A. Flood damage estimation based on flood simulation scenarios and a GIS platform. Eur. Water 2010, 30, 3-11. 
51. Masood, M.; Takeuchi, K. Assessment of flood hazard, vulnerability and risk of mid-eastern Dhaka using DEM and 1D hydrodynamic model. Nat. Hazards 2012, 61, 757-770. [CrossRef]

52. Khattak, M.S.; Anwar, F.; Saeed, T.U.; Sharif, M.; Sheraz, K.; Ahmed, A. Floodplain mapping using HEC-RAS and ArcGIS: A case study of Kabul River. Arab. J. Sci. Eng. 2016, 41, 1375-1390. [CrossRef]

53. Rahmati, O.; Zeinivand, H.; Besharat, M. Flood hazard zoning in Yasooj region, Iran, using GIS and multi-criteria decision analysis. Geomat. Nat. Hazards Risk 2016, 7, 1000-1017. [CrossRef]

54. Teng, J.; Jakeman, A.J.; Vaze, J.; Croke, B.F.; Dutta, D.; Kim, S. Flood inundation modelling: A review of methods, recent advances and uncertainty analysis. Environ. Model. Softw. 2017, 90, 201-216. [CrossRef]

55. Papaioannou, G.; Vasiliades, L.; Loukas, A.; Aronica, G.T. Probabilistic flood inundation mapping at ungauged streams due to roughness coefficient uncertainty in hydraulic modelling. Adv. Geosci. 2017, 44, 23-34. [CrossRef]

56. Guan, M.; Liang, Q. A two-dimensional hydro-morphological model for river hydraulics and morphology with vegetation. Environ. Model. Softw. 2017, 88, 10-21. [CrossRef]

57. Civilian Protection of Spain: Study of Historical floods in the Duero river basin. Available online: http: / / www.proteccioncivil.es/catalogo/naturales/cnih/cnih2014/PDF/B6/Documenta2/CTEI_DUERO (accessed on 10 October 2018).

58. Tormes Gauging Yearbook, Public Works Study and Experimentation Centre, Govern of Spain. Available online: http:/ / ceh-flumen64.cedex.es / anuarioaforos / afo / estaf-datos.asp?indroea=2087 (accessed on 11 October 2018).

59. UNDRO. Mitigating Natural Disasters; Phenomena, Effects and Options United Nations: New York, NY, USA, 1991.

60. Leskens, J.G.; Kehl, C.; Tutenel, T.; Kol, T.; De Haan, G.; Stelling, G.; Eisemann, E. An interactive simulation and visualization tool for flood analysis usable for practitioners. Mitig. Adapt. Strateg. Glob. Chang. 2017, 22, 307-324. [CrossRef]

61. Ernst, J.; Dewals, B.J.; Detrembleur, S.; Archambeau, P.; Erpicum, S.; Pirotton, M. Micro-scale flood risk analysis based on detailed 2D hydraulic modelling and high resolution geographic data. Nat. Hazards 2010, 55, 181-209. [CrossRef]

62. Vacondio, R.; Dal Palù, A.; Ferrari, A.; Mignosa, P.; Aureli, F.; Dazzi, S. A non-uniform efficient grid type for GPU-parallel Shallow Water Equations models. Environ. Model. Softw. 2017, 88, 119-137. [CrossRef]

63. Zischg, A.P.; Mosimann, M.; Bernet, D.B.; Roethlisberger, V. Validation of 2D flood models with insurance claims. J. Hydrol. 2018, 557, 350-361. [CrossRef]

64. Macchione, F.; Costabile, P.; Costanzo, C.; De Santis, R. Moving to 3-D flood hazard maps for enhancing risk communication. Environ. Model. Softw. 2019, 111, 510-522. [CrossRef]

65. Leskens, J.G.; Brugnach, M.; Hoekstra, A.Y.; Schuurmans, W. Why are decisions in flood disaster management so poorly supported by information from flood models? Environ. Model. Softw. 2014, 53, 53-61. [CrossRef]

66. Hagemeier-Klose, M.; Wagner, K. Evaluation of flood hazard maps in print and web mapping services as information tools in flood risk communication. Nat. Hazards Earth Syst. Sci. 2009, 9, 563-574. [CrossRef]

67. Costabile, P.; Macchione, F.; Natale, L.; Petaccia, G. Flood mapping using LIDAR DEM. Limitations of the 1-D modeling highlighted by the 2-D approach. Nat. Hazards 2015, 77, 181-204. [CrossRef]

68. Shen, D.; Wang, J.; Cheng, X.; Rui, Y.; Ye, S. Integration of 2-D hydraulic model and high-resolution lidar-derived DEM for floodplain flow modeling. Hydrol. Earth Syst. Sci. 2015, 19, 3605-3616. [CrossRef]

69. Silva, P.G.; López, M.; Roquero, E.; Huerta, P.; Martínez-Graña, A.M. Chronology of fluvial terrace sequences for Large Atlantic Rivers in the Iberian Peninsula (Upper Tagus and Duero drainage basins, Central Spain). Quat. Sci. Rev. 2017, 166, 188-203. [CrossRef]

(C) 2018 by the authors. Licensee MDPI, Basel, Switzerland. This article is an open access article distributed under the terms and conditions of the Creative Commons Attribution (CC BY) license (http://creativecommons.org/licenses/by/4.0/). 